Article

\title{
Copper Nanoparticle and Nitrogen Doped Graphite Oxide Based Biosensor for the Sensitive Determination of Glucose
}

\author{
Kulandaivel Sivasankar ${ }^{1}$, Karuppasamy Kohila Rani ${ }^{2}$, Sea-Fue Wang ${ }^{2, *}$, \\ Rajkumar Devasenathipathy ${ }^{2}$ and Chia-Her Lin ${ }^{1,3, * \text { (i) }}$
}

1 Department of Chemistry, Chung-Yuan Christian University, Chungli District, Taoyuan City 32023, Taiwan; sivasankarmpm@gmail.com

2 Department of Materials and Mineral Resources Engineering, National Taipei University of Technology, No. 1, Sec. 3, Chung-Hsiao East Rd., Taipei 106, Taiwan; kokirackz@gmail.com (K.K.R.); chemrackz@gmail.com (R.D.)

3 R\&D Center for Membrane Technology, Chung-Yuan Christian University, Chungli District, Taoyuan City 32023, Taiwan

* Correspondence: sfwang@ntut.edu.tw (S.-F.W.); chiaher@cycu.edu.tw (C.-H.L.); Tel.: +886-3-2653315 (C.-H.L.); Fax: +886-3-2653399 (C.-H.L.)

Received: 19 May 2018; Accepted: 10 June 2018; Published: 13 June 2018

\begin{abstract}
Copper nanoparticles with the diameter of $50 \pm 20 \mathrm{~nm}$ decorated nitrogen doped graphite oxide (NGO) have been prepared through a simple single step carbonization method using copper metal-organic framework (MOF), $\left[\mathrm{Cu}_{2}(\mathrm{BDC})_{2}(\mathrm{DABCO})\right]$ (where $\mathrm{BDC}$ is 1,4-benzenedicarboxylate, and $\mathrm{DABCO}$ is 1,4-Diazabicyclo[2.2.2]octane) as precursor. The surface morphology, porosity, surface area and elemental composition of CuNPs/NGO were characterized by various techniques. The as-synthesized CuNPs/NGO nanomaterials were coated on commercially available disposable screen-printed carbon electrode for the sensitive determination of glucose. We find that the modified electrode can detect glucose between $1 \mu \mathrm{M}$ and $1803 \mu \mathrm{M}$ (linear range) with good sensitivity $\left(2500 \mu \mathrm{A} \mathrm{mM}^{-1} \mathrm{~cm}^{-2}\right)$. Our glucose sensor also possesses low limits of detection $(0.44 \mu \mathrm{M})$ towards glucose determination. The highly selective nature of the fabricated electrode was clearly visible from the selectivity studies. The practicability of CuNPs/NGO modified electrode has been validated in the human serum samples. The storage stability along with better repeatability and reproducibility results additionally substantiate the superior electrocatalytic activity of our constructed sensor towards glucose.
\end{abstract}

Keywords: metal-organic framework; copper nanoparticles; nitrogen doped graphite oxide; amperometric techniques; glucose; human serum samples

\section{Introduction}

At present, the development of glucose biosensors have received more interest in the diagnosis of human blood sugar level, food industry and waste water treatment [1,2]. The detection of glucose has been performed using several methods such as fluorescent spectrometer [3], liquid chromatography [4], and electrochemical sensors [5]. Compared to other methods, electrochemical methods have gained the preference in bio-sensing research because of their facile approach, good repeatability, high selectivity and low cost [6]. The miniscule screen printed carbon electrodes (SPCEs) have been introduced in the development of fast and accurate sensing devices. These SPCEs are non-reusable, cost effective and are also comprised of three electrodes on planar strips [7-9]. The electrochemical experiments involving SPCEs have several advantages such as: (i) no effect of oxygen interference (ii) measurements in 
micro-volumes of sample solutions are possible and (iii) no need for mechanical polishing of electrode surface [5]. In contrast to these advantages, the use of bare (unmodified) electrodes in the enzyme less electrochemical detection leads to certain drawbacks like poor electron transfer, high over potential and electrode fouling. The surface of SPCEs has been chemically modified by the present-day researchers to sense the desirable analytes [7]. These modified electrodes are chosen to overcome the above shortcomings in the non-enzymatic electrochemical determination of glucose [10,11].

Several carbon based metal and metal oxide have been utilized for the fabrication of non-enzymatic glucose biosensors as they possess high surface area, good sensitivity, selectivity and electrocatalytic activity towards glucose. Advantages such as non-toxicity and low cost of copper have attracted the researchers in the fabrication of low cost biosensors $[12,13]$ compared to noble metals $(\mathrm{Au}$, Pt and Pd) [14-16]. Notably, these copper based nanomaterials show higher catalytic activity towards the oxidation of glucose than that of other common metal nanomaterials such as nickel, manganese, cobalt, etc. [17-19]. Therefore, many synthetic protocols have been developed for the preparation of copper based nanocomposites. In order to increase the dispersion and decrease the aggregation of copper nanoparticles, certain carbon materials (graphene, carbon nanotubes (CNTs), and carbon block, etc.) are used as matrices by the current researchers [12,20,21]. Interestingly, N-doped carbon materials provide high surface area and a large number of active sites for the incorporation of copper nanoparticles without any aggregation. For example, Ding et al. synthesized copper nanoparticles decorated N-doped graphene for the fabrication of glucose biosensor where they reported an enhanced electrochemical activity towards glucose compared only copper nanoparticles [22]. However, the preparation of electrodes based on binder-free carbon/Cu composite materials remains challenging.

Metal-organic frameworks (MOFs) are one of the industrialized hybrid porous materials and it has a buildup of metal ions/clusters linked through organic linkers, which presents a diverse network architecture, topology, desirable pore size and high surface area. Along with many application perceptive, MOFs are utilized in heterogeneous catalysis [23], gas storage [24], colorimetric bio sensing [25] and drug delivery [26]. In particular, MOFs are attractive candidates for sensing and biosensing applications, for example: electrocatalyst supporting matrix for electrochemical sensors in the detection of glucose, acetaminophen dopamine, nicotinamide adenine dinucleotide (NADH), catechol and hydroquinone hydrogen peroxide, and cysteine [27-34]. However, most of the MOF are unstable in air moisture, and, hence, their water-based application has been limited. In order to overcome the above issue, MOFs have been carbonized under inert atmosphere to produce the metal- or metal oxide-embedded carbon composite materials, named carbonized MOFs (CMOFs). Furthermore, the CMOFs showed high surface areas and ordered pores as like their parent MOFs, which is well-suited for many applications including biosensors.

Motivated by the benefits of CMOFs, this work presents the synthesis of copper nanoparticles decorated with nitrogen doped graphite oxide (CuNPs/NGO) (without addition of binder) through direct carbonization of a copper $\mathrm{MOF},\left[\mathrm{Cu}_{2}(\mathrm{BDC})_{2}(\mathrm{DABCO})\right]$ (where $\mathrm{BDC}$ is 1,4-benzenedicarboxylate, and DABCO is 1,4-diazabicyclo[2.2.2] octane). Various carbonization temperatures $\left(700,800\right.$, and $\left.900{ }^{\circ} \mathrm{C}\right)$ were used to study the effect of temperature in the synthesis of CuNPs/NGO. The prepared $\mathrm{CuNPs}$ /NGO were coated on screen-printed carbon electrode for the fabrication of electrochemical sensors. Our fabricated CuNPs/NGO/SPCE showed a good electrochemical activity of CuNPs/NGO towards the determination of glucose. The obtained electroanalytical performances in terms of limits of detection (LOD), quick amperometric response, high sensitivity, attractive selectivity and a wide linear range are good or comparable with formerly reported literature Moreover, the accurate determination of glucose in human serum samples confirms the practical feasibility of CuNPs/NGO nanocomposite. 


\section{Experimental Section}

\subsection{Materials and Methods}

Copper (III) nitrate $\left(\mathrm{Cu}\left(\mathrm{NO}_{3}\right)_{2} \cdot 3 \mathrm{H}_{2} \mathrm{O}\right.$, Showa ( $\left.\geq 99.9 \%\right)$, Tokyo, Japan), dimethylformamide (DMF, Merck ( $\geq 99.8 \%$ ), Darmstdt, Germany), 1,4-benzene dicarboxylate (BDC, Sigma-Aldrich (98\%), Burlington, MA, USA), 1,4-diazabicyclo[2.2.2]octane (DABCO, Alfa Aesar (98\%), Lancashire, UK), glucose and sodium hydroxide $(\mathrm{NaOH})$ were purchased from Sigma-Aldrich (Darmstdt, Germany) at an analytical grade. The electrochemical experiments were done using $0.1 \mathrm{M} \mathrm{NaOH}$ as the supporting electrolyte. Prior to each experiment, all the solutions were deoxygenated with pre-purified $\mathrm{N}_{2}$ gas for $15 \mathrm{~min}$. All of the electrochemical measurements were carried out with double distilled water, which has a conductivity of $\geq 18 \mathrm{M} \Omega \mathrm{cm}$. Human blood serum sample was collected from valley biomedical, Taiwan product \& services, Inc. This study was reviewed and approved by the ethics committee of Chang-Gung memorial hospital through the contract no. IRB101-5042A3.

\subsection{Apparatus}

The phase purity of all the compounds was examined by powder X-ray diffraction (PXRD) using a Bruker D8 PHASER instrument (Billerica, MA, USA). The synthesized CMOFs were also characterized using a micro-Raman module with a He-Ne laser $(632.8 \mathrm{~nm})$. The charge-coupled device (CCD) exposure time was varied from 5 to $20 \mathrm{~s}$. Raman shifts were calibrated using the silicon (Si) reference peak at $521 \mathrm{~cm}^{-1}$. The $\mathrm{N}_{2}$ gas sorption isotherms were measured at $77 \mathrm{~K}$ using an ASAP 2020 system of Micrometrics (Norcross, GA, USA). Ultrahigh purity grade $\mathrm{N}_{2}$, and He were used as received. Before the gas sorption measurements, the sample was initially dehydrated at $423 \mathrm{~K}$ for $24 \mathrm{~h}$ under vacuum. A high resolution scanning electron microscopy (HRSEM, using a JEOL JEM-7600F instrument, Akishima, Japan) and transmission electron microscopy (TEM, using a JEM-2010 instrument, Tokyo, Japan) were employed to characterize the morphology. The $\mathrm{Cu}$ content was analyzed by using an Inductively Coupled Plasma-Mass Spectrometer (ICP-MS) (Japan Agilent 7500ce, Tokyo, Japan) after the sample was dissolved, and the elemental analysis was performed on an Elementar vario EL III CHN-OS elemental analyzer (Germany). The electrochemical measurements were carried out through CHI 6171D work station with a conventional three electrode cell, which uses modified SPCE $\left(\right.$ area $\left.=0.071 \mathrm{~cm}^{2}\right)$, saturated $\mathrm{Ag} \mid \mathrm{AgCl}$ (saturated $\mathrm{KCl}$ ) and Pt wire as working, reference and counter electrodes, respectively. An analytical rotator AFMSRX (PINE instruments, Grove City, PA, USA) with a rotating disc glassy carbon electrode $\left(\mathrm{RDE}\right.$, area $\left.=0.21 \mathrm{~cm}^{2}\right)$ was utilized in the amperometric i-t measurements.

\subsection{Preparation of $\left[C u_{2}(B D C)_{2}(D A B C O)\right]$}

All reagents and solvents employed were used without any further purification. The bulk $\mathrm{MOF},\left[\mathrm{Cu}_{2}(\mathrm{BDC})_{2}(\mathrm{DABCO})\right]$ materials were synthesized by solvothermal methods as described in literature [35]. Typically, a mixture of $\mathrm{Cu}\left(\mathrm{NO}_{3}\right)_{2} \cdot 3 \mathrm{H}_{2} \mathrm{O}(3 \mathrm{mmol}, 725 \mathrm{mg}), \mathrm{H}_{2} \mathrm{BDC}(3 \mathrm{mmol}, 498 \mathrm{mg})$, and DABCO $(2.49 \mathrm{mmol}, 279 \mathrm{mg})$ was taken in a conical flask containing $60 \mathrm{~mL}$ of DMF and stirred at room temperature for $20 \mathrm{~min}$, followed by $20 \mathrm{~min}$ of sonication. The mixture was transferred into a Teflon-lined autoclave and heated at $120{ }^{\circ} \mathrm{C}$ for $48 \mathrm{~h}$. After that, the mixture was cooled to room temperature. The blue colored solid product was filtered, washed thoroughly with DMF for the removal of unreacted reagents and dried overnight at room temperature under vacuum. The dried material was transferred into a vacuum desiccator and further used for the preparation of carbonized MOF (CMOF).

\subsection{Preparation of $\mathrm{CuNPS} / \mathrm{NGO}$}

The CuNPs/NGO materials were synthesized through simple one-step direct carbonization method. In addition, $400 \mathrm{mg}$ of $\left[\mathrm{Cu}_{2}(\mathrm{BDC})_{2}(\mathrm{DABCO})\right]$ was carefully taken in a silica boat and placed inside the furnace chamber. The chamber was evacuated and $\mathrm{N}_{2}$ gas was passed in to the chamber for 
$1 \mathrm{~h}$ to create $\mathrm{N}_{2}$ atmosphere. Then, the MOF was heated to $600{ }^{\circ} \mathrm{C}$ under $\mathrm{N}_{2}$ atmosphere at a heating rate of $5{ }^{\circ} \mathrm{C} \mathrm{min}{ }^{-1}$. The temperature was maintained at $600{ }^{\circ} \mathrm{C}$ for $5 \mathrm{~h}$ and then cooled to room temperature with a cooling rate of $1^{\circ} \mathrm{C} \mathrm{min}^{-1}$. The carbonization of $\left[\mathrm{Cu}_{2}(\mathrm{BDC})_{2}(\mathrm{DABCO})\right] \mathrm{MOF}$ under $\mathrm{N}_{2}$ atmosphere leads to the formation of copper nanoparticles decorated with Nitrogen-functionalized graphite oxide (CuNPs/NGO). The resulting carbonized sample was transferred to a sample tube, sealed with paraffin film and noted as CuNPs/NGO (600) based on the carbonization temperature. By following the similar procedure, CuNPs/NGO (700), CuNPs/NGO (800) and CuNPs/NGO (900) were also prepared.

\subsection{Electrode Fabrication}

Furthermore, $2 \mathrm{mg}$ of all the carbonized CuNPs/NGO samples was individually dispersed in $1 \mathrm{~mL}$ of DMF. The electrode (glassy carbon electrode) surface was pre-polished with a Buehler polishing kit (MicroCloth, Magnetic, 8 in, Tokyo, Japan) using ET033 $0.05 \mu \mathrm{m}$ alumina slurry, washed and air-dried in the oven. Later, the $10 \mu \mathrm{L}$ of CuNPs/NGO sample was drop cast onto the surface SPCE and dried at suitable conditions. The resulting modified electrode was utilized for the electrochemical studies.

\section{Results and Discussion}

\subsection{Formation of $\left[C u_{2}(B D C)_{2}(D A B C O)\right]$}

The precursor $\mathrm{MOF},\left[\mathrm{Cu}_{2}(\mathrm{BDC})_{2}(\mathrm{DABCO})\right]$ for the construction of $\mathrm{Cu}$ nanoparticle embedded nitrogen functionalized graphite oxide materials is comprised of dinuclear $\mathrm{Cu}_{2}$ units with a paddle wheel structure, bridged by BDC dianions forms a distorted $2 \mathrm{D}$ square-grid $\left[\mathrm{Cu}_{2}(\mathrm{BDC})_{2}\right]$. The axial sites of $\mathrm{Cu}_{2}$ paddle wheels are occupied by DABCO, which acts as pillars for the extension of 2D layers into a 3D structure (Figure 1). Accordingly, $\left[\mathrm{Cu}_{2}(\mathrm{BDC})_{2}(\mathrm{DABCO})\right] \mathrm{MOF}$ was prudently selected as the nitrogen functionalized graphite oxide precursor. $\left[\mathrm{Cu}_{2}(\mathrm{BDC})_{2}(\mathrm{DABCO})\right]$ prepared under the solvothermal conditions exhibits a pure phase of crystalline material, as-synthesized PXRD patterns showed in Figure $\mathrm{S} 1$ and $\mathrm{N}_{2}$ gas sorption technique was used to determine the surface area of prepared $\mathrm{MOF}\left[\mathrm{Cu}_{2}(\mathrm{BDC})_{2}(\mathrm{DABCO})\right]$ in Figure S2.

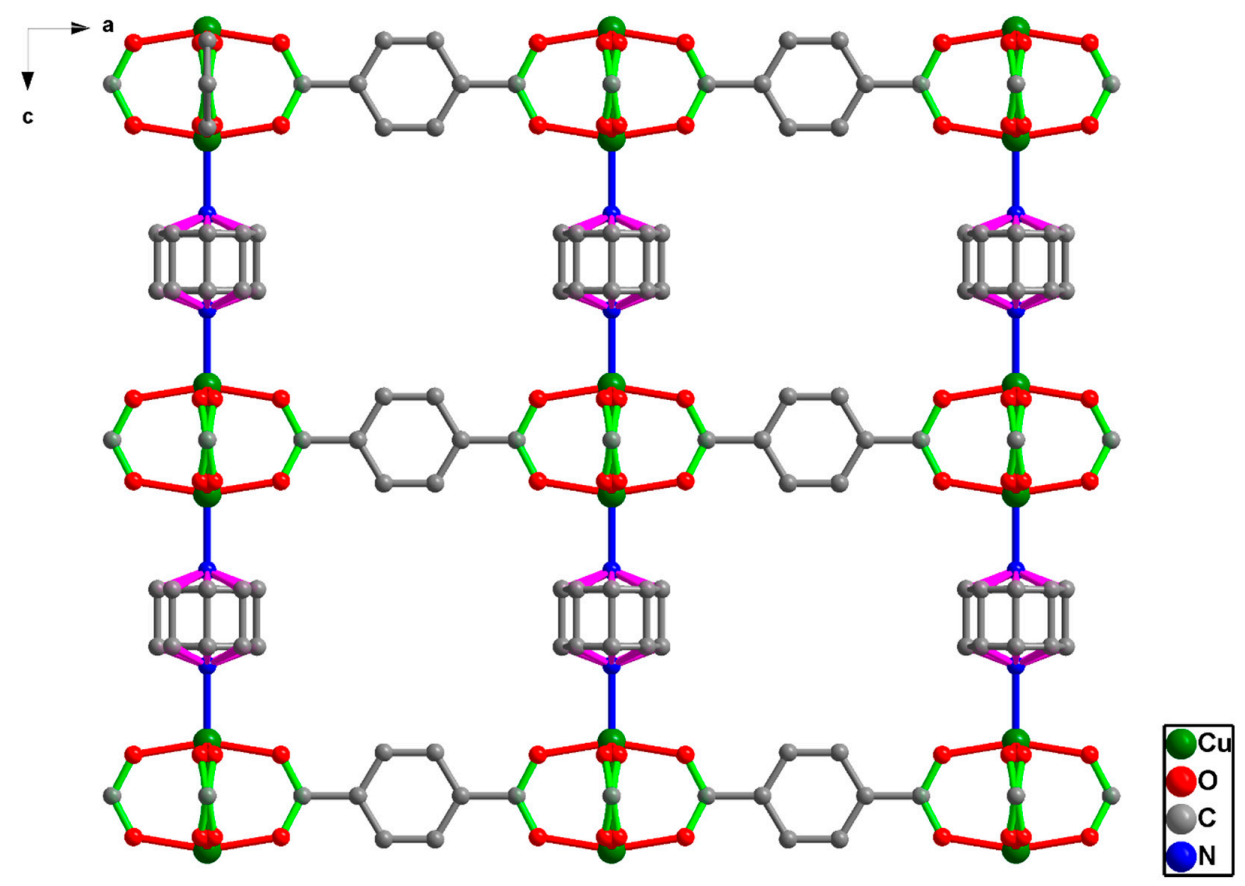

Figure 1. Crystal structure of $\left[\mathrm{Cu}_{2}(\mathrm{BDC})_{2}(\mathrm{DABCO})\right]$ along the $b$-axis (hydrogen atoms are not given for the sake of clarity). 


\subsection{Characterization of Prepared $\mathrm{CuNPS/NGO} \mathrm{Nanocomposite}$}

The morphologies of $\mathrm{Cu}$ nanoparticles decorated nitrogen doped graphite oxide were studied by scanning electron microscopy (SEM) and transmission electron microscopy (TEM). The SEM image of the prepared parent $\mathrm{MOF}\left[\mathrm{Cu}_{2}(\mathrm{BDC})_{2}(\mathrm{DABCO})\right]$ displayed the single uniform trigonal and tetragonal structures (Figure 2A), whereas the SEM images of CuNPs/NGO (carbonized at $600{ }^{\circ} \mathrm{C}(\mathrm{B}), 700{ }^{\circ} \mathrm{C}(\mathrm{C})$, $800^{\circ} \mathrm{C}(\mathrm{D}), 900^{\circ} \mathrm{C}(\mathrm{E})$ ) clearly illustrate that the composite also comprises $\mathrm{Cu}$ and $\mathrm{Cu}_{2} \mathrm{O}$ nanoparticles along with the amorphous carbon bed. In the composite material carbonized at high temperature $\left(900{ }^{\circ} \mathrm{C}\right), \mathrm{Cu}$ nanoparticles are non-uniformly (diameter of $50 \pm 20 \mathrm{~nm}$ ) embedded into the amorphous carbon bed. This was supported by the TEM image in Figure 2F.

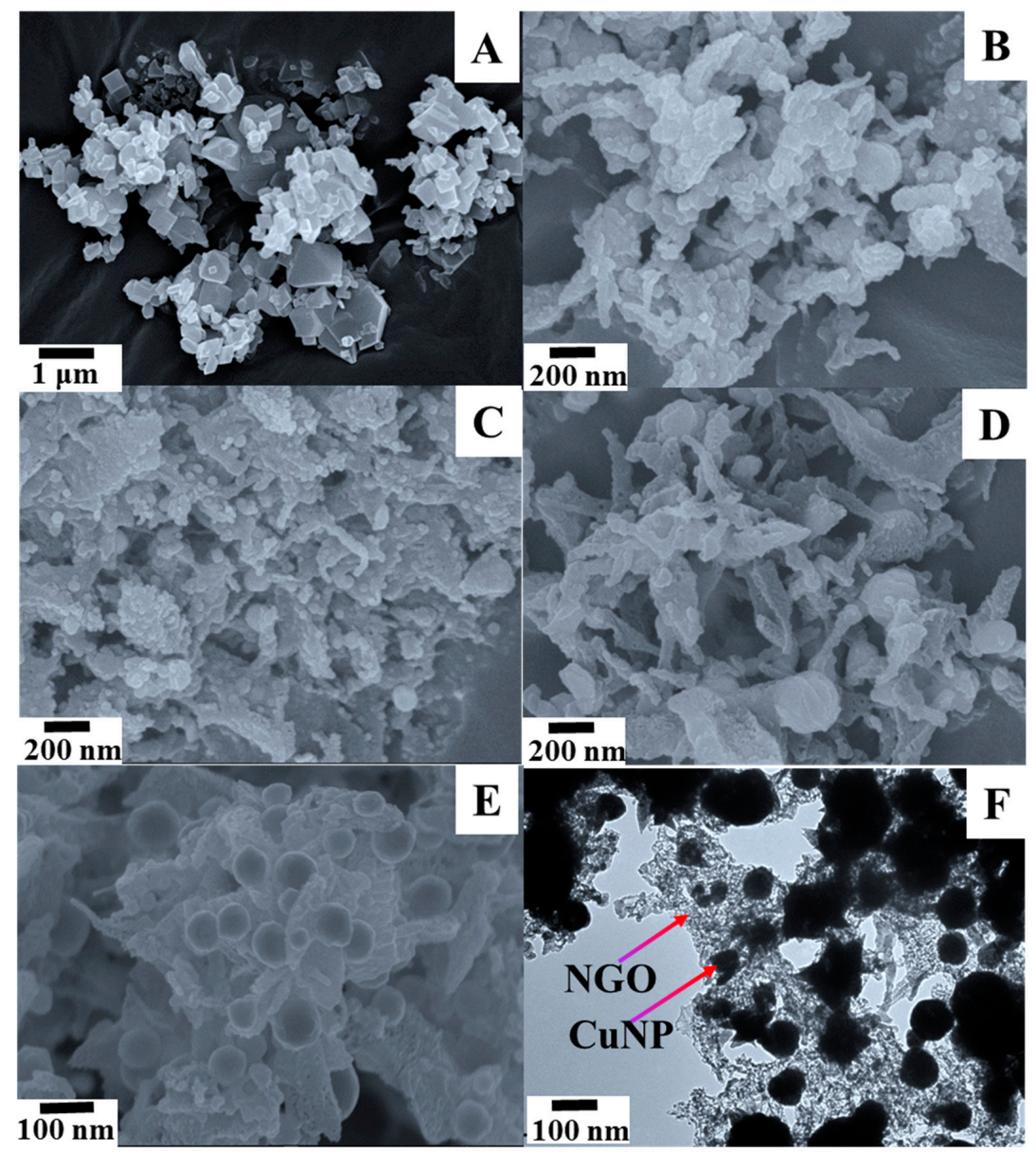

Figure 2. SEM images of only MOF (A); CuNPs/NGO (carbonized at $600{ }^{\circ} \mathrm{C}(\mathbf{B}) ; 700{ }^{\circ} \mathrm{C}(\mathbf{C}) ; 800{ }^{\circ} \mathrm{C}(\mathbf{D})$; $900^{\circ} \mathrm{C}(\mathbf{E})$; and TEM image $(\mathbf{F})$ of CuNPs $\left./ \mathrm{NGO}\left(900^{\circ} \mathrm{C}\right)\right)$.

The combined study of inductively coupled Plasma-Mass spectrometry (ICP-MS) and Elemental analysis (EA) reveals the weight percentages of various elements present in CuNPs/NGO composite (Table 1). Detailed elemental information about copper, nitrogen, carbon and oxygen confirms the high weight percentage of copper relative to other elements. The lower weight percentage of oxygen compared to copper supports the formation of copper nanoparticles instead of $\mathrm{Cu}_{2} \mathrm{O}$. The occurrence of nitrogen in appreciable quantity indicates the nitrogen functionalization in the prepared composite. This available nitrogen content can enhance the electrical conductivity of CuNPs/NGO and the nitrogen containing functional groups can probably react with glucose molecules through van der Waals forces as well as hydrogen bonding. 
Table 1. Atom distribution in the $\mathrm{Cu}$ nanoparticles decorated nitrogen doped graphite oxide, which was assessed by using ICP-MS $(\mathrm{Cu})$ and elemental analysis $(\mathrm{N}, \mathrm{C}, \mathrm{H}$ and $\mathrm{O})$.

\begin{tabular}{cccccc}
\hline Sample & Cu wt \% & N wt \% & C wt \% & H wt \% & O wt \% \\
\hline CuNPs/NGO(600) & 71.63 & 2.10 & 22.84 & 1.72 & 1.71 \\
CuNPs/NGO(700) & 71.68 & 1.96 & 22.73 & 1.79 & 1.84 \\
CuNPs/NGO(800) & 71.34 & 1.94 & 23.82 & 1.83 & 1.07 \\
CuNPs/NGO(900) & 77.43 & 1.44 & 17.21 & 1.19 & 2.73 \\
\hline
\end{tabular}

The crystal structure and the phase purity of the carbonized products were examined through Powder X-ray diffraction (PXRD) and presented in Figure 3. The obtained PXRD patterns were consistent with the pattern of CuNPs/NGO composite. The enhanced diffraction peaks at $43.33^{\circ}$, $50.47^{\circ}$ and $74.12^{\circ}$ can be assigned to the (111), (200) and (220) crystal planes of $\mathrm{Cu}^{(0)}$ (Joint Committee on Powder Diffraction Standards-JCPDS) (JCPDS, No. 65-9026) [36]. The diffraction peaks at 29.63\%, $36.43^{\circ}, 42.33^{\circ}$ and $61.52^{\circ}$ can be assigned to the (110), (111), (200) and (220) planes of $\mathrm{Cu}_{2} \mathrm{O}$ (JCPDS, No. 05-0667). The particle size of $\mathrm{Cu}_{2} \mathrm{O}$ particles estimated from the Scherer equation using the PXRD data was approximately $12 \mathrm{~nm}$ at $600{ }^{\circ} \mathrm{C}$, and increased to 26,44 and $50 \mathrm{~nm}$ at 700,800 and $900{ }^{\circ} \mathrm{C}$, respectively. Notably, the formation of $\mathrm{Cu}_{2} \mathrm{O}$ is higher in CuNPs/NGO (600), but the formation of $\mathrm{Cu}^{(0)}$ is higher in CuNPs/NGO (900). It indicates that the copper reduction (from $\mathrm{Cu}^{(\mathrm{II})}->\mathrm{Cu}^{(0)}$ ) was increased upon increasing of annealing temperature from $600{ }^{\circ} \mathrm{C}$ to $900^{\circ} \mathrm{C}$. Moreover, a new peak at $11.8^{\circ}$ was also observed in the CuNPs/NGO(900), which can be due to the (001) reflection of graphite oxide (GO) [37].

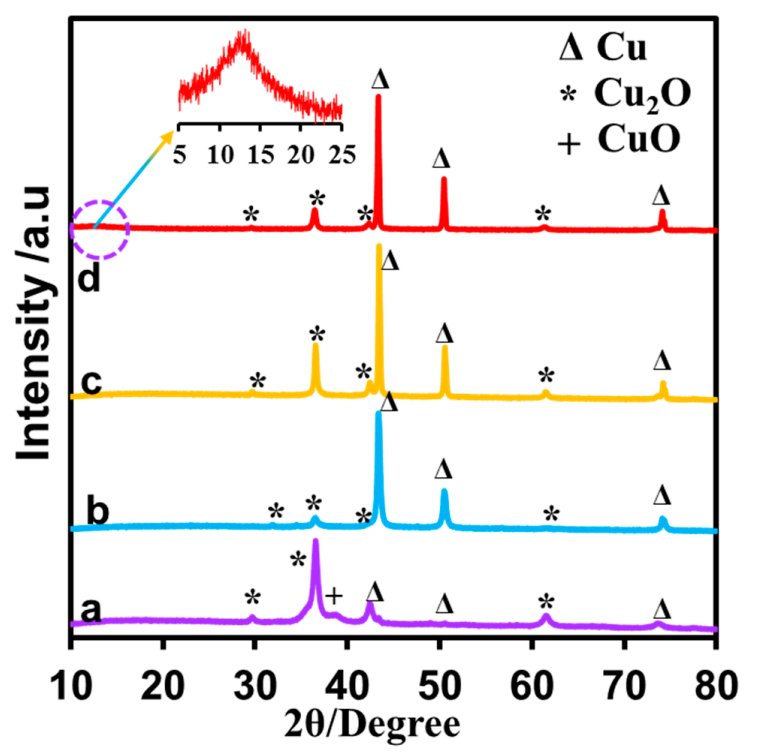

Figure 3. XRD pattern of CuNPs/NGO (carbonized at $600{ }^{\circ} \mathrm{C}(\mathbf{a}), 700{ }^{\circ} \mathrm{C}(\mathbf{b}), 800{ }^{\circ} \mathrm{C}(\mathbf{c})$ and $\left.900{ }^{\circ} \mathrm{C}(\mathbf{d})\right)$.

The low degree graphitization of nitrogen-functionalized graphite oxide material was further characterized by Raman spectroscopy. The D and G bands between $1200 \mathrm{~cm}^{-1}$ and $1600 \mathrm{~cm}^{-1}$ were analyzed by fitting with Gaussian profiles. Gaussian fitting possesses better fitting accuracy and was also used in analyzing the presence of amorphous carbons. Thus, the simultaneous fitting of the spectra with four bands has been accomplished: $1180 \mathrm{~cm}^{-1}$ (A1 band), $1350 \mathrm{~cm}^{-1}$ (D band), $1500 \mathrm{~cm}^{-1}$ (A2 band), and $1580 \mathrm{~cm}^{-1}$ (G band). The Raman spectrum in CuNPs/NGO (carbonized at $600^{\circ} \mathrm{C} \mathrm{(a),}$ $700{ }^{\circ} \mathrm{C}(\mathrm{b}), 800^{\circ} \mathrm{C}(\mathrm{c})$ and $\left.900^{\circ} \mathrm{C}(\mathrm{d})\right)$ represents the combination of $\mathrm{A} 1$ and $\mathrm{D}$ bands as a broad peak and so the $\mathrm{A} 1$ and $\mathrm{D}$ band separation as well as the determination of $\mathrm{D}$ and $\mathrm{G}$ peak positions were achieved using Gaussian fitting after the baseline subtraction (Figure S3). D band intensity shows the existence 
of defects, edge effects and dangling $\mathrm{sp}^{2}$ carbon bonds that break the symmetry and disorder-induced effects for any type of carbon. The appearance of the $G$ peak is due to the in-plane stretching motion between $\mathrm{sp}^{2}$ carbon atoms and $A_{2}$ band, an indication of the existence of amorphous carbon [38]. The order of intensity ratio $\left(I_{\mathrm{D}} / I_{\mathrm{G}}\right.$ ratio) is CuNPs/NGO $(600)<\mathrm{CuNPs} / \mathrm{NGO}(700)<\mathrm{CuNPs} / \mathrm{NGO}$ $(800)<\mathrm{CuNPs} / \mathrm{NGO}$ (900). This indicates the formation of disorderliness, defect carbons and low degree of graphitization in the obtained CuNPs/NGO (900) material.

The porosity and surface areas of the CuNPs/NGO materials were analyzed by $\mathrm{N}_{2}$ adsorption experiments at $77 \mathrm{~K}$ (Figure $4 \mathrm{~A}$ ). The results imply that the prepared samples possess a 3D network and the carbonization at high temperature under $\mathrm{N}_{2}$ atmosphere leads to nitrogen functionalized carbon content of the composites. The CMOFs are composed of multilayer amorphous carbon and additionally they have the essential influence of the accessibility of Glucose molecules into the CuNP catalytic surface sites. Even though the CMOFs have extremely decreased surface area, these materials unveiled interesting hierarchical porosity. Table 2 displays the surface area, porosity and pore volume of CuNPs/NGO materials. From Figure 4B, CuNPs/NGO $\left(600{ }^{\circ} \mathrm{C}(\mathrm{a})\right), \mathrm{CuNPs} / \mathrm{NGO}\left(700{ }^{\circ} \mathrm{C}(\mathrm{b})\right)$, and CuNPs/NGO $\left(800^{\circ} \mathrm{C}\right.$ (c)) displayed a considerable surface area and hierarchical porosity. The surface area $\left(114 \mathrm{~m}^{2} \mathrm{~g}^{-1}\right)$ of CuNPs/NGO $\left(\left(800{ }^{\circ} \mathrm{C}\right)\right.$ was slightly smaller compared to the surface areas of $\mathrm{CuNPs} / \mathrm{NGO}\left(600^{\circ} \mathrm{C}\right)$ and $\left.\mathrm{CuNPs} / \mathrm{NGO}\left(700^{\circ} \mathrm{C}\right)\right)$. In addition, the existence of CuNPs into the composite at higher temperature changes the pore size distribution. In these materials, hierarchical porosity affords better accessibility of the glucose on catalytic sites of CuNPs/NGO nanocomposites, while CuNPs/NGO $\left(900^{\circ} \mathrm{C}(\mathrm{d})\right)$ material owns a small surface area and micro porous pore volume because of the presence of CuNPs on the surface of amorphous carbon layer. Thus, the better accessibility of glucose molecule is possible through the catalytic sites of CuNPs. As a result, a better non-enzymatic catalytic activity of the composite materials is expected at higher temperatures.

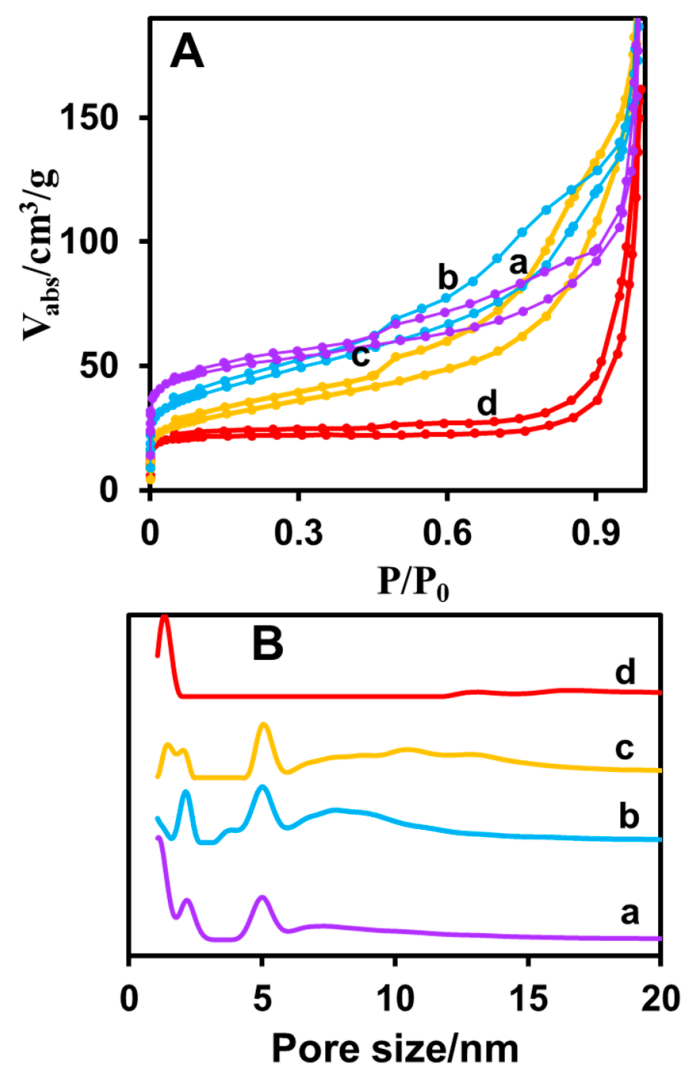

Figure 4. (A) $\mathrm{N}_{2}$ adsorption analysis of CuNPs/NGO (600 (a), 700 (b), 800 (c) and $900{ }^{\circ} \mathrm{C}$ (d)); (B) pore size distribution curves of CuNPs/NGO (600 (a), 700 (b), 800 (c) and $\left.900{ }^{\circ} \mathrm{C}(\mathrm{d})\right)$. 
Table 2. The BET surface areas and pore sizes of CuNPs/NGO (600, 700, 800 and 900).

\begin{tabular}{ccccc}
\hline \multirow{2}{*}{ Sample } & \multicolumn{2}{c}{ Surface $\mathbf{A r e a} / \mathbf{m}^{\mathbf{2}} \mathbf{g}^{\mathbf{- 1}}$} & \multirow{2}{*}{ Total Pore Volume (cc/g) $\mathbf{P / P o} \sim \mathbf{0 . 9 9}$} & Pore Size (nm) \\
\cline { 2 - 3 } & BET & Langmuir & & \\
\hline CuNPs/NGO(600) & 185 & 193 & 0.31 & 2,5 \\
CuNPs/NGO(700) & 144 & 151 & 0.34 & $2,3-5$ \\
CuNPs/NGO(800) & 108 & 113 & 0.32 & $1-2,5$ \\
CuNPs/NGO(900) & 86 & 90 & 0.25 & 1.2 \\
\hline
\end{tabular}

\subsection{Electrochemical Behavior of $\mathrm{CuNPs/NGO} \mathrm{Nanocomposites}$}

The electrochemical ability of unmodified and modified CuNPs/NGO $\left(600,700,800\right.$ and $\left.900{ }^{\circ} \mathrm{C}\right)$ screen printed electrode (SPCE) towards the oxidation of glucose was studied by the cyclic voltammetry (CV) method. The concentration of $\mathrm{NaOH}(0.1 \mathrm{M})$ and the scan rate $(50 \mathrm{mV} / \mathrm{s})$ were fixed for the cyclic voltammetric experiments. The unmodified SPCE showed the small anodic peak current towards the oxidation of glucose (Figure S4). This indicates the poor electron transfer, high over potential and electrode fouling of unmodified SPCE. However, a well-defined anodic peak appeared for the CuNPs/NGO (600 (A), 700 (B), 800 (C) and $900{ }^{\circ} \mathrm{C}$ (D) Figure 5) modified SPCEs in the presence of $1 \mathrm{mM}$ glucose. A large anodic peak current $\left(I_{\mathrm{p}}=0.706 \mathrm{~mA}\right)$ was observed for CuNPs $/ \mathrm{NGO}\left(900{ }^{\circ} \mathrm{C}\right)$ towards the electro-oxidation of $1 \mathrm{mM}$ glucose compared to other CuNPs $/ \mathrm{NGO}\left(I_{\mathrm{p}}=0.476 \mathrm{~mA}\right.$ $\left(600{ }^{\circ} \mathrm{C}\right), I_{\mathrm{p}}=0.493 \mathrm{~mA}\left(700^{\circ} \mathrm{C}\right)$ and $\left.I_{\mathrm{p}}=0.538 \mathrm{~mA}\left(800^{\circ} \mathrm{C}\right)\right)$ modified electrodes. This can be due to the higher carbonization of CuNPs/NGO $\left(900^{\circ} \mathrm{C}\right)$ relative to others. Moreover, a large background current was also obtained for CuNPs/NGO $\left(900^{\circ} \mathrm{C}\right)$ compared to CuNPs/NGO $\left(600,700\right.$, and $\left.800{ }^{\circ} \mathrm{C}\right)$ as presented in Figure 5. This observation revealed the synergistic effect between the good conductivity of NGO and good catalytic activity of CuNPs present in the prepared nanocomposites. To study the effect of loading at CuNPs/NGO $\left(900{ }^{\circ} \mathrm{C}\right)$ towards electro-oxidation of glucose, we have chosen four different concentrations $(0.5,1,2$ and $2.5 \mathrm{mg} / \mathrm{mL}$ (DMF)) and their corresponding voltammograms were given in Figure S5. From the CVs, it revealed that maximum electrochemical ability was attained at $2 \mathrm{mg} / \mathrm{mL}$ loaded CuNPs/NGO $\left(900{ }^{\circ} \mathrm{C}\right)$ modified SPCE. For the sake of clarity, CuNPs/NGO $\left(900^{\circ} \mathrm{C}\right)$ will be referred to as CuNPs/NGO for the remaining electrochemical studies. The possible electrochemical mechanism at CuNPs/NGO towards the oxidation of glucose is given below [39]:

$$
\begin{gathered}
\mathrm{Cu}+\mathrm{OH}^{-} \rightarrow \mathrm{Cu}(\mathrm{OH})_{2}+2 \mathrm{e}^{-}, \\
\mathrm{Cu}(\mathrm{OH})_{2}+\mathrm{OH}^{-} \rightarrow \mathrm{CuOOH}+\mathrm{e}^{-}, \\
\mathrm{CuOOH}+\mathrm{e}^{-}+\text {glucose } \rightarrow \mathrm{Cu}(\mathrm{OH})_{2}+\text { glucolactone. }
\end{gathered}
$$

The cyclic voltammetry technique was also used to study the influence of glucose concentration at CuNPs/NGO modified SPCE. The experiment was carried out in $0.1 \mathrm{M} \mathrm{NaOH}$ at the fixed scan rate $(50 \mathrm{mV} / \mathrm{s})$ in the absence (a) and presence (b-k) of glucose (Figure 6). No noticeable anodic peak was observed at CuNPs/NGO/SPCE in the absence of glucose, whereas a well-defined and enhanced anodic peak appeared in the presence of $1 \mathrm{mM}$ glucose. Moreover, a linear increase in the anodic peaks was attained upon increasing the concentration of glucose (each addition of $1 \mathrm{mM}$ glucose). In addition, the linear dependency between $I_{\mathrm{p}}$ and (glucose) was observed in the equivalent calibration plot, indicating the good electrocatalytic ability of CuNPs/NGO/SPCE towards the determination of glucose. 

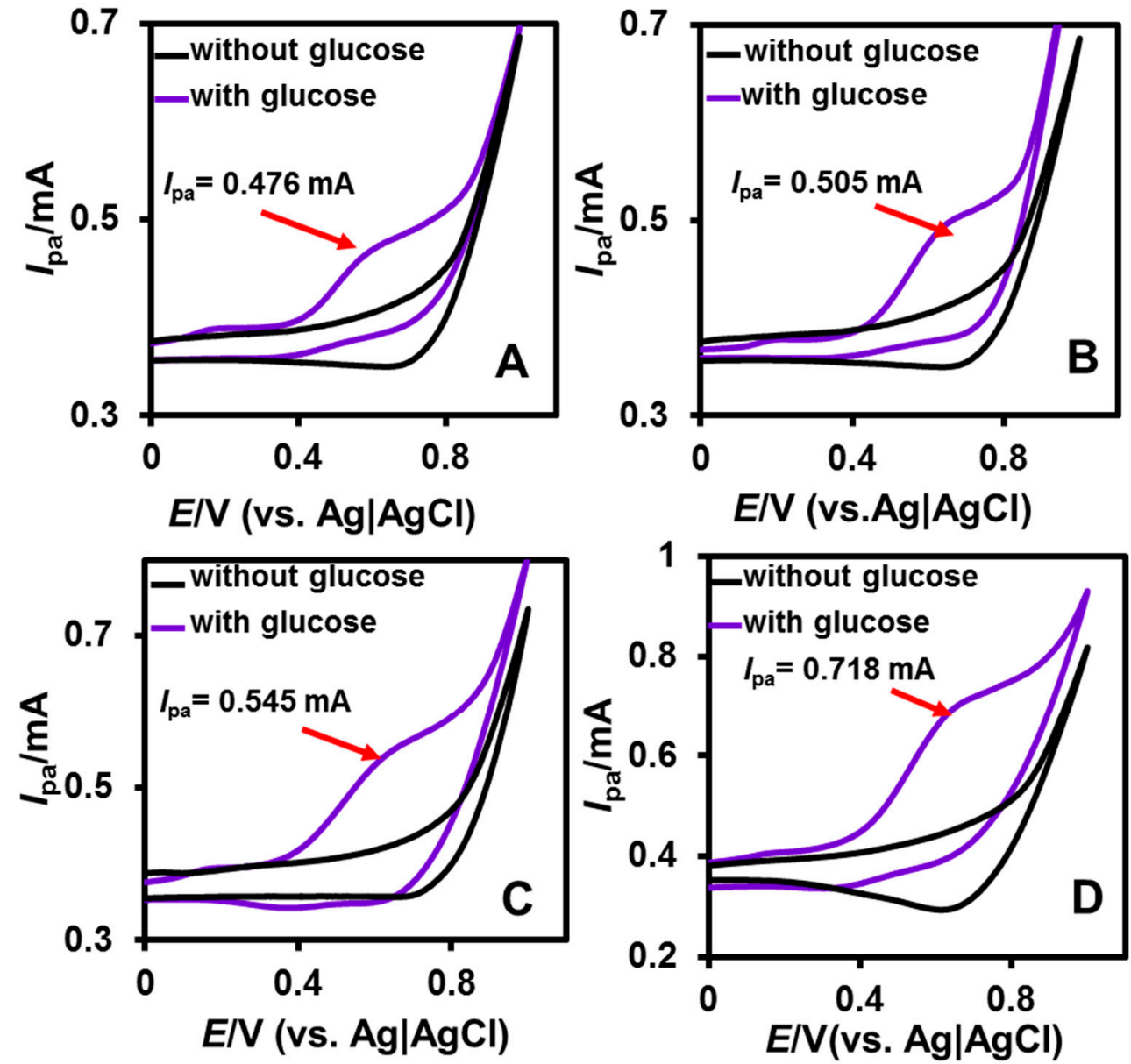

Figure 5. CVs obtained at CuNPs/NGO (600 (A), 700 (B), 800 (C) and $900{ }^{\circ} \mathrm{C}($ D) $)$ modified SPCEs in $0.1 \mathrm{NaOH}$ with and without $3 \mathrm{mM}$ glucose at the scan rate of $50 \mathrm{mV} / \mathrm{s}$.

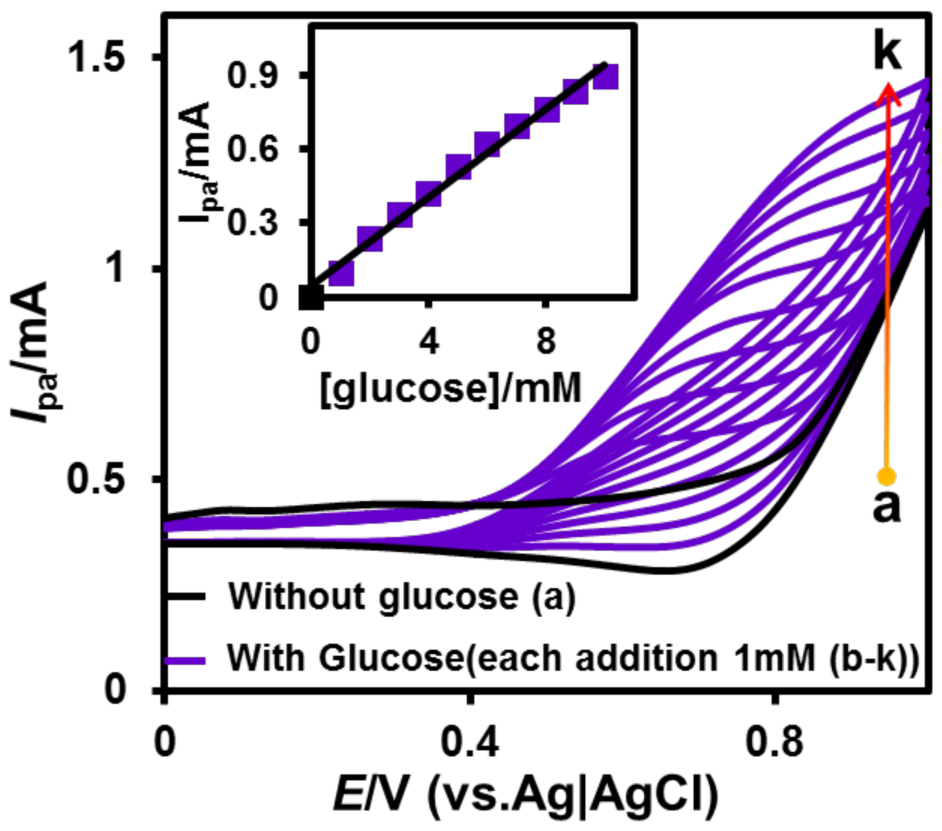

Figure 6. CVs observed without (a) and with each addition (b-k) of $1 \mathrm{mM}$ glucose at CuNPs/ $\mathrm{NGO} / \mathrm{SPCE}$ in $0.1 \mathrm{M} \mathrm{NaOH}$ at the scan rate of $50 \mathrm{mV} / \mathrm{s}$. 


\subsection{Amperometric i-t Determination}

Figure 7A presents the amperometric i-t response at CuNPs/NGO/SPCE for the addition of varying glucose concentrations into the constantly stirred $0.1 \mathrm{M} \mathrm{NaOH}$. The rotation speed and applied potential were held at $1500 \mathrm{rpm}$ and $0.4 \mathrm{~V}$. A quick and well-defined peak current response was observed for each consecutive addition of glucose $(1,10,50,100$ and $200 \mu \mathrm{M}(\mathrm{a}-\mathrm{e}))$ indicating the outstanding catalytic ability of CuNPs/NGO modified SPCE towards the electro-oxidation of glucose. In addition, the $95.25 \%$ steady state current response attained within $3 \mathrm{~s}$ for each addition of glucose supports the excellent electrocatalytic activity of the fabricated electrode. The values of electroanalytical parameters such as linear range $(1-1803 \mu \mathrm{M})$, limits of detection (LOD, $0.44 \mu \mathrm{M})$ and sensitivity $\left(2500 \mu \mathrm{A} \mathrm{mM}^{-1} \mathrm{~cm}^{-2}\right)$ were evaluated from the linear calibration plot between concentration of glucose and peak current response (Figure 7B). LOD $=3 s_{\mathrm{b}} / S$ (where, $s_{\mathrm{b}}=$ standard deviation of blank signal and $S=$ sensitivity) was the equation applied in the calculation of sensitivity. The assessed electroanalytical parameters of CuNPs/NGO/SPCE were compared (Table 3) and found to be in close agreement with the earlier reported linear range, LOD and sensitivity values of the glucose sensors from the literature. The obtained sensitivity is higher, but the LOD is not so good compared with other examples [40-49]. This may be due to the size of the nanoparticles, and the amount of depositions of nanoparticles on the carbon materials.
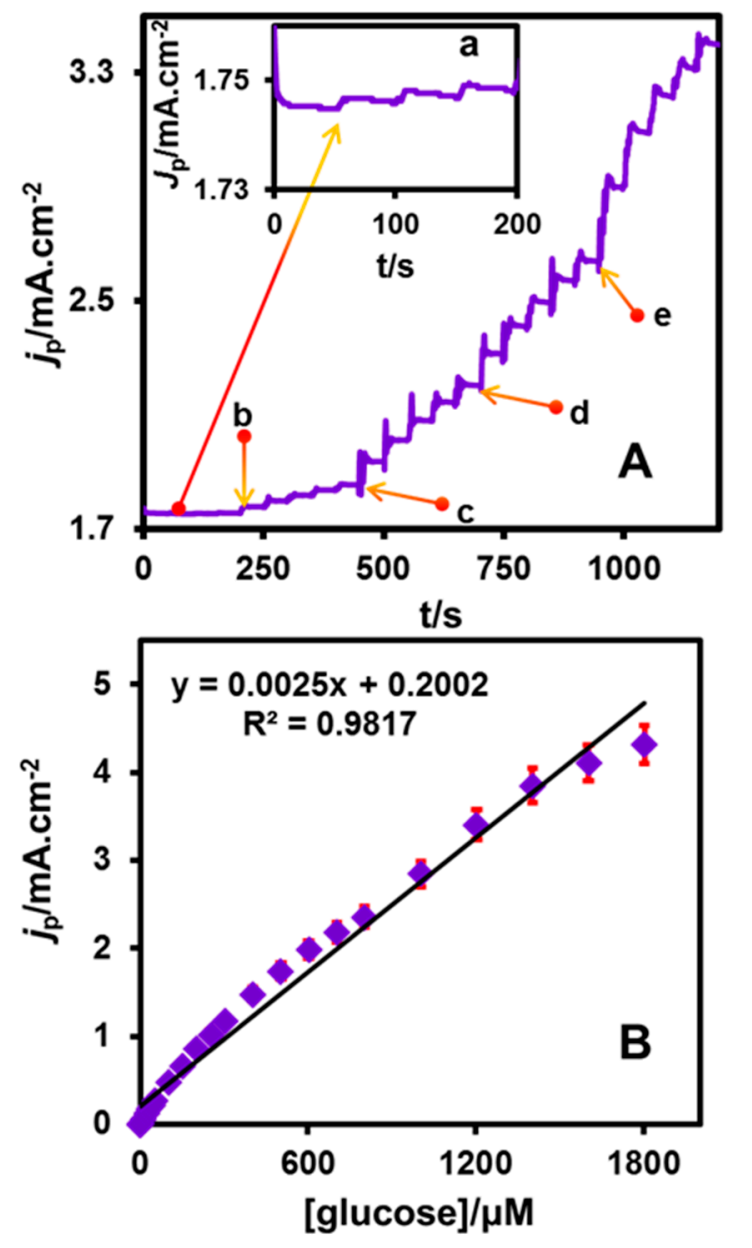

Figure 7. (A) amperometric response at CuNPs/NGO/SPCE upon successive additions of glucose (1, 10, 50,100 and $200 \mu \mathrm{M}(\mathrm{a}-\mathrm{e})$ ) of glucose in $0.1 \mathrm{M} \mathrm{NaOH}$ (scan rate $=50 \mathrm{mV} \mathrm{s}^{-1}$, applied potential $=0.4 \mathrm{~V}$ ); (B) calibration plot of $I_{\mathrm{p}}$ vs. (glucose). 
Table 3. Comparison of electroanalytical parameters for the determination of glucose at CuNPs/NGO nanocomposite modified electrode with previously reported modified electrodes.

\begin{tabular}{|c|c|c|c|c|}
\hline Modified Electrode & ${ }^{a} \operatorname{LR}(\mu \mathrm{M})$ & ${ }^{b}$ LOD $(\mu M)$ & Sensitivity & Ref. \\
\hline 3D N-Co-CNT@NG) & $25-10,830$ & 0.1 & $9.05 \mu \mathrm{A} \mathrm{mM}^{-1} \mathrm{~cm}^{-2}$ & [40] \\
\hline $\mathrm{Cu@porous} \mathrm{carbon}$ & $1-6000$ & 0.6 & 10,100 & [41] \\
\hline$\left[\mathrm{Cu}_{3}\left({ }^{\mathrm{C}} \mathrm{btc}\right)_{2}\right]$ nanocube & $1-2250$ & 1 & $549 \mu \mathrm{A} \mathrm{mM}^{-1} \mathrm{~cm}^{-2}$ & [42] \\
\hline $\mathrm{Cu}^{-\mathrm{d}} \mathrm{BDD}$ & $1-50$ & 10 & $2.3 \mu \mathrm{A} \mathrm{mM}^{-1} \mathrm{~cm}^{-2}$ & [43] \\
\hline N-doped Carbon-Cu nanohybrids & $5-2100$ & 0.7 & $223.6 \mu \mathrm{A} \mathrm{mM}^{-1} \mathrm{~cm}^{-2}$ & [44] \\
\hline Graphene oxide and $\mathrm{NiO}$ nanofibers & $2-600$ & 0.77 & 1100 & [45] \\
\hline Cu nanoporous & $10-500$ & 40 & $220 \mu \mathrm{A} \mathrm{mM}^{-1} \mathrm{~cm}^{-2}$ & [46] \\
\hline $\mathrm{Cu}$ NPs/SWCNTs & $0.5-500$ & 0.3 & $0.256 \mu \mathrm{A} \mathrm{mM}^{-1} \mathrm{~cm}^{-2}$ & [47] \\
\hline $\mathrm{Cu} / \mathrm{CuO} / \mathrm{ZnO}$ & $100-1000$ & 18 & $408 \mu \mathrm{A} \mathrm{mM}^{-1} \mathrm{~cm}^{-2}$ & [48] \\
\hline $\mathrm{AuCu} / \mathrm{CNTs}$ & $80-9260$ & 4 & $22 \mu \mathrm{AmM}^{-1} \mathrm{~cm}^{-2}$ & [49] \\
\hline CuNPs/NGO & $1-1803$ & 0.44 & $2500 \mu \mathrm{A} \mathrm{mM} \mathrm{m}^{-1} \mathrm{~cm}^{-2}$ & This work \\
\hline
\end{tabular}

${ }^{a}$ LR-linear range, ${ }^{b}$ LOD—limits of detection, ${ }^{c}$ btc-Benzene-1,3,5-tricarboxylate, ${ }^{d}$ BDD—boron doped diamond electrode.

\subsection{Selectivity Studies}

The experiment to examine the selectivity nature of CuNPs/NGO/SPCE towards glucose was performed in the presence of various interfering biomolecules, which can be oxidized at the same optimized potential $(0.4 \mathrm{~V})$ applied for the electro-oxidation of glucose. The selectivity of our modified electrode was studied (Figure S6) under the similar experimental conditions as mentioned in Section 3.4. Biological interferents such as sucrose, dopamine, uric acid, and ascorbic acid were taken in $0.1 \mathrm{mM}$ concentration compared to glucose $(1 \mathrm{mM})$. Since the concentration of chosen interferents is less than $0.1 \mathrm{mM}$ in human blood serum, $0.1 \mathrm{mM}$ concentration of common interferents have been chosen for the selectivity studies. An enhanced anodic peak current response was visualized at CuNPs/NGO modified SPCE with respect to $1 \mathrm{mM}$ addition of glucose. In contrast, the addition of other interfering biomolecules $(0.1 \mathrm{mM})$ showed no obvious peak response supporting the excellent catalytic activity of $\mathrm{CuNPs/NGO/SPCE}$ in the selective detection of glucose.

\subsection{Repeatability, Reproducibility and Stability}

The repeatability nature of CuNPs/NGO modified SPCE was investigated by executing six incessant experiments with single modified electrode towards $3 \mathrm{mM}$ glucose at the scan rate of $50 \mathrm{mV} / \mathrm{s}$. The corresponding relative standard deviation (RSD) value evaluated as $2.4 \%$ reveals the acceptable repeatability of our modified electrode. The reproducing capability was determined by conducting six independent measurements with six discreet fabricated electrodes. The obtained value of RSD (1.9\%) exposes the appreciable reproducibility of CuNPs/NGO modified SPCE (Table S1). In order to test the stability, the anodic peak response of CuNPs/NGO/SPCE towards $3 \mathrm{mM}$ glucose was recorded for a time period of 30 days, followed by storing the fabricated electrode at $4{ }^{\circ} \mathrm{C}$ in $0.1 \mathrm{M} \mathrm{NaOH}$. During the daily experiments, a well-defined anodic peak current response was displayed by our modified electrode without any shift of peak potential towards $3 \mathrm{mM}$ glucose. In addition, the final anodic peak response obtained at CuNPs/NGO modified SPCE was $96.2 \%$ of the initial peak current response (Table S2). Thus, our enzyme less glucose sensor holds considerable storage stability.

\subsection{Real Sample Analysis}

The demonstration of feasible practicality was done in the human serum samples collected from diabetes patients. The serum samples $(2 \mathrm{~mL})$ were diluted to $10 \mathrm{~mL}$ using $0.1 \mathrm{M} \mathrm{NaOH}$ and further utilized for the experiments under the above-mentioned experimental conditions in analyzing lab glucose samples. By employing the standard addition method, the concentration of glucose in the human serum samples were estimated as 5.16, 5.09, 6.73 and $6.49 \mathrm{mM}$. These values were in accordance with the values of glucose concentration $(5.31,5.05,6.85$ and $6.61 \mathrm{mM})$ evaluated by using 
the commercially available Tecan Sunrise plate reader (Table S3). The adequate recovery results imply the successful practicability of our CuNPs/NGO modified SPCE.

\section{Conclusions}

A highly selective amperometric glucose sensor was constructed based on the as-prepared CuNPs/NGO, working in a wide linear range from 1 to $1803 \mu \mathrm{M}$. Our modified constructed electrode holds low limits of detection $(0.44 \mu \mathrm{M})$ and high sensitivity $\left(2500 \mu \mathrm{A} \mathrm{mM} \mathrm{mm}^{-1} \mathrm{~cm}^{-2}\right)$. The unusually precise detection of glucose in the human serum samples exposes the fabricated electrode as a peculiar real-time glucose sensor. The additional advantages such as facile operational approach, increased porosity and outstanding catalytic activity towards the determination of glucose prolong the usage of CuNPs/NGO/SPCE for batteries, biosensors and super capacitors in the immediate future.

Supplementary Materials: The following are available online at http:/ /www.mdpi.com/2079-4991/8/6/429/s1. Figure S1. PXRD pattern of as-synthesized MOF $\left[\mathrm{Cu}_{2}(\mathrm{BDC})_{2}(\mathrm{DABCO})\right]$. Figure S2. $\mathrm{N}_{2}$ adsorption analysis of activated $\mathrm{MOF}\left[\mathrm{Cu}_{2}(\mathrm{BDC})_{2}(\mathrm{DABCO})\right]$. Figure S3. Raman spectra fitted with Gaussian profiles of CuNPs / NGO (carbonized at $600{ }^{\circ} \mathrm{C}(\mathrm{a}), 700{ }^{\circ} \mathrm{C}(\mathrm{b}), 800{ }^{\circ} \mathrm{C}$ (c) and $900{ }^{\circ} \mathrm{C}(\mathrm{d})$ ). Figure S4 CVs without (a) and with each addition (b-k) of $3 \mathrm{mM}$ glucose at unmodified SPCE in $0.1 \mathrm{M} \mathrm{NaOH}$ at the scan rate of $50 \mathrm{mV} / \mathrm{s}$. Figure S5. Voltammograms obtained at CuNPs/NGO modified SPCE for different loading concentrations $(0.5,1,2$ and $2.5 \mathrm{mg} / \mathrm{mL}$ (DMF)) of CuNPs/NGO. Figure S6. Selectivity study of CuNPs/NGO modified SPCE towards glucose (a) in presence of sucrose (b), dopamine (c), uric acid (d) and ascorbic acid (e). Table S1: Repeatability study at CuNPs/NGO modified SPCE in 5 different solutions towards $3 \mathrm{mM}$ Glucose and Reproducibility study at 5 different CuNPs/NGO modified SPCEs towards $3 \mathrm{mM}$ Glucose. Table S2: Stability study of 3 mM Glucose at CuNPs/NGO modified SPCE. Table S3. Determination of glucose in human blood serum samples.

Author Contributions: K.S., R.D., C.-H.L. and S.-F.W. conceived and designed the experiments; K.S. and K.K.R. performed the experiments, analyzed the data and wrote the paper; C.-H.L. and S.-F.W. contributed reagents/materials/analysis tools.

Acknowledgments: Financial assistance received from the Ministry of Science and Technology, Taiwan (MOST106-2113-M-033-001) and Chung Yuan Christian University are gratefully acknowledged. Rajkumar Devasenathipathy gratefully acknowledges the National Taipei University of Technology, Taiwan for the postdoctoral fellowship.

Conflicts of Interest: The authors declare no conflict of interest.

\section{References}

1. Wang, J. Carbon-nanotube based electrochemical biosensors: A review. Electroanalysis 2005, 17, 7-14. [CrossRef]

2. Ameen, S.; Akhtar, M.S.; Shin, H.S. Nanocages-augmented aligned polyaniline nanowires as unique platform for electrochemical non-enzymatic glucose biosensor. Appl. Catal. A Gen. 2016, 517, 21-29. [CrossRef]

3. Jin, L.; Shang, L.; Guo, S.; Fang, Y.; Wen, D.; Wang, L.; Yin, J.; Dong, S. Biomolecule-stabilized Au nanoclusters as a fluorescence probe for sensitive detection of glucose. Biosens. Bioelectron. 2011, 26, 1965-1969. [CrossRef] [PubMed]

4. Kamal, M.A.; Klein, P. Determination of sugars in honey by liquid chromatography. Saudi J. Biol. Sci. 2011, 18, 17-21. [CrossRef] [PubMed]

5. Mani, V.; Devasenathipathy, R.; Chen, S.-M.; Wang, S.-F.; Devi, P.; Tai, Y. Electrodeposition of copper nanoparticles using pectin scaffold at graphene nanosheets for electrochemical sensing of glucose and hydrogen peroxide. Electrochim. Acta 2015, 176, 804-810. [CrossRef]

6. Devasenathipathy, R.; Karuppiah, C.; Chen, S.-M.; Palanisamy, S.; Lou, B.-S.; Ali, M.A.; Al-Hemaid, F.M. A sensitive and selective enzyme-free amperometric glucose biosensor using a composite from multi-walled carbon nanotubes and cobalt phthalocyanine. RSC Adv. 2015, 5, 26762-26768. [CrossRef]

7. Rana, S.; Mittal, S.K.; Kaur, N.; Banks, C.E. Disposable screen printed electrode modified with imine receptor having a wedge bridge for selective detection of Fe (ii) in aqueous medium. Sens. Actuators B Chem. 2017, 249, 467-477. [CrossRef]

8. Renedo, O.D.; Alonso-Lomillo, M.; Martinez, M.A. Recent developments in the field of screen-printed electrodes and their related applications. Talanta 2007, 73, 202-219. [CrossRef] [PubMed] 
9. Honeychurch, K.C.; Hart, J.P.; Cowell, D.C.; Arrigan, D.W. Voltammetric behavior and trace determination of cadmium at a calixarene modified screen-printed carbon electrode. Electroanalysis 2002, 14, 177-185. [CrossRef]

10. Wang, G.; He, X.; Wang, L.; Gu, A.; Huang, Y.; Fang, B.; Geng, B.; Zhang, X. Non-enzymatic electrochemical sensing of glucose. Microchim. Acta 2013, 180, 161-186. [CrossRef]

11. Mu, Y.; Jia, D.; He, Y.; Miao, Y.; Wu, H.-L. Nano nickel oxide modified non-enzymatic glucose sensors with enhanced sensitivity through an electrochemical process strategy at high potential. Biosens. Bioelectron. 2011, 26, 2948-2952. [CrossRef] [PubMed]

12. Mei, L.; Zhang, P.; Chen, J.; Chen, D.; Quan, Y.; Gu, N.; Zhang, G.; Cui, R. Non-enzymatic sensing of glucose and hydrogen peroxide using a glassy carbon electrode modified with a nanocomposite consisting of nanoporous copper, carbon black and nafion. Microchim. Acta 2016, 183, 1359-1365. [CrossRef]

13. Liu, X.; Yang, W.; Chen, L.; Jia, J. Synthesis of copper nanorods for non-enzymatic amperometric sensing of glucose. Microchim. Acta 2016, 183, 2369-2375. [CrossRef]

14. Bai, Y.; Yang, W.; Sun, Y.; Sun, C. Enzyme-free glucose sensor based on a three-dimensional gold film electrode. Sens. Actuators B Chem. 2008, 134, 471-476. [CrossRef]

15. Rong, L.-Q.; Yang, C.; Qian, Q.-Y.; Xia, X.-H. Study of the nonenzymatic glucose sensor based on highly dispersed Pt nanoparticles supported on carbon nanotubes. Talanta 2007, 72, 819-824. [CrossRef] [PubMed]

16. Bai, H.; Han, M.; Du, Y.; Bao, J.; Dai, Z. Facile synthesis of porous tubular palladium nanostructures and their application in a nonenzymatic glucose sensor. Chem. Commun. 2010, 46, 1739-1741. [CrossRef] [PubMed]

17. Hameed, R.A. Amperometric glucose sensor based on nickel nanoparticles/carbon vulcan XC-72R. Biosens. Bioelectron. 2013, 47, 248-257. [CrossRef] [PubMed]

18. Wang, T.; Yu, Y.; Tian, H.; Hu, J. A novel non-enzymatic glucose sensor based on cobalt nanoparticles implantation-modified indium tin oxide electrode. Electroanalysis 2014, 26, 2693-2700. [CrossRef]

19. Chen, J.; Zhang, W.-D.; Ye, J.-S. Nonenzymatic electrochemical glucose sensor based on $\mathrm{MnO}_{2} / \mathrm{MWNT}^{2}$ nanocomposite. Electrochem. Commun. 2008, 10, 1268-1271. [CrossRef]

20. Luo, J.; Jiang, S.; Zhang, H.; Jiang, J.; Liu, X. A novel non-enzymatic glucose sensor based on Cu nanoparticle modified graphene sheets electrode. Anal. Chim. Acta 2012, 709, 47-53. [CrossRef] [PubMed]

21. Wu, H.-X.; Cao, W.-M.; Li, Y.; Liu, G.; Wen, Y.; Yang, H.-F.; Yang, S.-P. In situ growth of copper nanoparticles on multiwalled carbon nanotubes and their application as non-enzymatic glucose sensor materials. Electrochim. Acta 2010, 55, 3734-3740. [CrossRef]

22. Jiang, D.; Liu, Q.; Wang, K.; Qian, J.; Dong, X.; Yang, Z.; Du, X.; Qiu, B. Enhanced non-enzymatic glucose sensing based on copper nanoparticles decorated nitrogen-doped graphene. Biosens. Bioelectron. 2014, 54, 273-278. [CrossRef] [PubMed]

23. Kuo, C.-H.; Tang, Y.; Chou, L.-Y.; Sneed, B.T.; Brodsky, C.N.; Zhao, Z.; Tsung, C.-K. Yolk-shell nanocrystal@ZIF-8 nanostructures for gas-phase heterogeneous catalysis with selectivity control. J. Am. Chem. Soc. 2012, 134, 14345-14348. [CrossRef] [PubMed]

24. Ma, S.; Zhou, H.-C. Gas storage in porous metal-organic frameworks for clean energy applications. Chem. Commun. 2010, 46, 44-53. [CrossRef] [PubMed]

25. Ai, L.; Li, L.; Zhang, C.; Fu, J.; Jiang, J. Mil-53 (Fe): A metal-organic framework with intrinsic peroxidase-like catalytic activity for colorimetric biosensing. Chem. A Eur. J. 2013, 19, 15105-15108. [CrossRef] [PubMed]

26. Horcajada, P.; Serre, C.; Maurin, G.; Ramsahye, N.A.; Balas, F.; Vallet-Regi, M.; Sebban, M.; Taulelle, F.; Férey, G. Flexible porous metal-organic frameworks for a controlled drug delivery. J. Am. Chem. Soc. 2008, 130, 6774-6780. [CrossRef] [PubMed]

27. Yuan, B.; Zhang, J.; Zhang, R.; Shi, H.; Wang, N.; Li, J.; Ma, F.; Zhang, D. Cu-based metal-organic framework as a novel sensing platform for the enhanced electro-oxidation of nitrite. Sens. Actuators B Chem. 2016, 222, 632-637. [CrossRef]

28. Shi, L.; Zhu, X.; Liu, T.; Zhao, H.; Lan, M. Encapsulating Cu nanoparticles into metal-organic frameworks for nonenzymatic glucose sensing. Sens. Actuators B Chem. 2016, 227, 583-590. [CrossRef]

29. Yang, J.; Zhao, F.; Zeng, B. One-step synthesis of a copper-based metal-organic framework-graphene nanocomposite with enhanced electrocatalytic activity. RSC Adv. 2015, 5, 22060-22065. [CrossRef]

30. Zhang, Y.; Bo, X.; Luhana, C.; Wang, H.; Li, M.; Guo, L. Facile synthesis of a Cu-based MOF confined in macroporous carbon hybrid material with enhanced electrocatalytic ability. Chem. Commun. 2013, 49, 6885-6887. [CrossRef] [PubMed] 
31. Chen, Q.; Li, X.; Min, X.; Cheng, D.; Zhou, J.; Li, Y.; Xie, Z.; Liu, P.; Cai, W.; Zhang, C. Determination of catechol and hydroquinone with high sensitivity using MOF-graphene composites modified electrode. J. Electroanal. Chem. 2017, 789, 114-122. [CrossRef]

32. Hosseini, H.; Ahmar, H.; Dehghani, A.; Bagheri, A.; Tadjarodi, A.; Fakhari, A.R. A novel electrochemical sensor based on metal-organic framework for electro-catalytic oxidation of 1-cysteine. Biosens. Bioelectron. 2013, 42, 426-429. [CrossRef] [PubMed]

33. Zhang, C.; Wang, M.; Liu, L.; Yang, X.; Xu, X. Electrochemical investigation of a new Cu-MOF and its electrocatalytic activity towards $\mathrm{H}_{2} \mathrm{O}_{2}$ oxidation in alkaline solution. Electrochem. Commun. 2013, 33, 131-134. [CrossRef]

34. Arul, P.; John, S.A. Electrodeposition of $\mathrm{CuO}$ from -Cu-MOF on glassy carbon electrode: A non-enzymatic sensor for glucose. J. Electroanal. Chem. 2017, 799, 61-69. [CrossRef]

35. Chaemchuen, S.; Zhou, K.; Kabir, N.A.; Chen, Y.; Ke, X.; Van Tendeloo, G.; Verpoort, F. Tuning metal sites of DABCO MOF for gas purification at ambient conditions. Microporous Mesoporous Mater. 2015, 201, 277-285. [CrossRef]

36. Yin, H.; Cui, Z.; Wang, L.; Nie, Q. In situ reduction of the $\mathrm{Cu} / \mathrm{Cu}_{2} \mathrm{O}$ carbon spheres composite for enzymaticless glucose sensors. Sens. Actuators B Chem. 2016, 222, 1018-1023. [CrossRef]

37. Zu, Y.; Tang, J.; Zhu, W.; Zhang, M.; Liu, G.; Liu, Y.; Zhang, W.; Jia, M. Graphite oxide-supported CaO catalysts for transesterification of soybean oil with methanol. Bioresour. Technol. 2011, 102, 8939-8944. [CrossRef] [PubMed]

38. Gong, Y.T.; Li, B.H.; Pei, T.; Lin, C.H.; Lee, S. Raman investigation on carbonization process of metal-organic frameworks. J. Raman Spectrosc. 2016, 47, 1271-1275. [CrossRef]

39. Liu, X.; Long, L.; Yang, W.; Chen, L.; Jia, J. Facilely electrodeposited coral-like copper micro-/nano-structure arrays with excellent performance in glucose sensing. Sens. Actuators B Chem. 2018, 266, 853-860. [CrossRef]

40. Balamurugan, J.; Thanh, T.D.; Karthikeyan, G.; Kim, N.H.; Lee, J.H. A novel hierarchical 3D N-Co-CNT@NG nanocomposite electrode for non-enzymatic glucose and hydrogen peroxide sensing applications. Biosens. Bioelectron. 2017, 89, 970-977. [CrossRef] [PubMed]

41. Zhang, X.; Luo, J.; Tang, P.; Morante, J.R.; Arbiol, J.; Xu, C.; Li, Q.; Fransaer, J. Ultrasensitive binder-free glucose sensors based on the pyrolysis of in situ grown Cu-MOF. Sens. Actuators B Chem. 2018, 254, $272-281$. [CrossRef]

42. Liu, Y.; Zhang, Y.; Chen, J.; Pang, H. Copper metal-organic framework nanocrystal for plane effect nonenzymatic electro-catalytic activity of glucose. Nanoscale 2014, 6, 10989-10994. [CrossRef] [PubMed]

43. Watanabe, T.; Ivandini, T.A.; Makide, Y.; Fujishima, A.; Einaga, Y. Selective detection method derived from a controlled diffusion process at metal-modified diamond electrodes. Anal. Chem. 2006, 78, 7857-7860. [CrossRef] [PubMed]

44. Wei, C.; Liu, Y.; Li, X.; Zhao, J.; Ren, Z.; Pang, H. Nitrogen-doped carbon-copper nanohybrids as electrocatalysts in $\mathrm{H}_{2} \mathrm{O}_{2}$ and glucose sensing. ChemElectroChem 2014, 1, 799-807. [CrossRef]

45. Zhang, Y.; Wang, Y.; Jia, J.; Wang, J. Nonenzymatic glucose sensor based on graphene oxide and electrospun $\mathrm{NiO}$ nanofibers. Sens. Actuators B Chem. 2012, 171, 580-587. [CrossRef]

46. Sattayasamitsathit, S.; Thavarungkul, P.; Thammakhet, C.; Limbut, W.; Numnuam, A.; Buranachai, C.; Kanatharana, P. Fabrication of nanoporous copper film for electrochemical detection of glucose. Electroanalysis 2009, 21, 2371-2377. [CrossRef]

47. Male, K.B.; Hrapovic, S.; Liu, Y.; Wang, D.; Luong, J.H. Electrochemical detection of carbohydrates using copper nanoparticles and carbon nanotubes. Anal. Chim. Acta 2004, 516, 35-41. [CrossRef]

48. SoYoon, S.; Ramadoss, A.; Saravanakumar, B.; Kim, S.J. Novel Cu/CuO/ZnO hybrid hierarchical nanostructures for non-enzymatic glucose sensor application. J. Electroanal. Chem. 2014, 717, 90-95. [CrossRef]

49. Liu, D.; Luo, Q.; Zhou, F. Nonenzymatic glucose sensor based on gold-copper alloy nanoparticles on defect sites of carbon nanotubes by spontaneous reduction. Synth. Met. 2010, 160, 1745-1748. [CrossRef]

(C) 2018 by the authors. Licensee MDPI, Basel, Switzerland. This article is an open access article distributed under the terms and conditions of the Creative Commons Attribution (CC BY) license (http://creativecommons.org/licenses/by/4.0/). 